\title{
Can We Predict the Likelihood of Financial Distress in Companies from their Corporate Governance and Borrowing?
}

\begin{abstract}
Purpose - A primary aim of the study is to investigate the impact of corporate governance structures on the likelihood of financial distress in U.K. listed companies. The paper examines the impact of borrowing and corporate governance structures on financial distress likelihood in U.K. companies.
\end{abstract}

Design/methodology/approach - The study uses a quantitative approach with financial, governance and borrowing measures and data from 270 firm-observations between 2010 and 2018 . The study analyses the impact of borrowing and corporate governance structures to indicate financial distress likelihood in British companies. Corporate governance variables such as ownership concentration, independence indicators, CEO duality, director remuneration and corporate loans are considered, as well as the UK Corporate Governance Code.

Findings - The results indicate that companies with low ownership concentration, and low degree of independence are more likely to incur financial distress. Larger boards and better director remuneration can reduce financial distress likelihood and the existence of corporate loans can increase this likelihood. Empirical consideration of corporate borrowing is a new contribution to the literature.

Originality - Variables are highlighted and aggregated that have not otherwise been studied together; the UK Corporate Governance Code's main ideas are empirically supported; the study is useful for defining corporate governance structure strategies.

Keywords: Corporate Borrowing, Corporate Governance, Financial Distress, Director Remuneration 


\section{Introduction}

Financial distress and bankruptcy impact on companies and the business world every day (Altman, 1968; Pindado et al, 2008; Manzaneque et al, 2016). Studying contributing factors to that phenomenon is essential, Furthermore, understanding how corporate governance affects financial distress should be a central tool, allowing better structures, more efficient operations, improving information transparency, safeguarding stakeholders, and helping mitigate risks.

Corporate borrowing and governance characteristics are enormously important in studying company financial distress likelihood. The influence of corporate governance structures on financial distress likelihood is studied, alongside the variables apparently affecting this likelihood. The relationship of corporate governance structures and borrowing with financial distress likelihood in UK listed companies is a central question explored, applying a model with mainly corporate governance variables, to identify structures that may increase financial distress likelihood.

The UK Corporate Governance Code will additionally be considered. It concerns responsibilities of shareholders and directors and remuneration and independence of the latter (FRC, 2019) ${ }^{1}$.

Financial ratios are one of the most critical factors in predicting financial distress and firm performance (Manzaneque et al, 2016; Chen, 2008; Altman, 1968; Pindado et al, 2008). The study's financial distress model covers the main financial ratios of Pindado et al (2008), Altman (1968) and Ohlson (1980), alongside empirical studies of corporate governance predicting financial distress. Variables such as ownership concentration, shareholder independence, board size, CEO duality, director remuneration and corporate loans are considered, with their connection to agency theory, which will also be considered.

Financial and corporate governance data from 270 UK listed companies across nine years (2010 2018) is examined with half the companies exhibiting financial distress and half being healthy. Evaluating the relationship between financial distress and corporate governance, including variables denoting other characteristics apparently not analysed to date, contributes to the existing literature. Corporate loans, director remuneration, and shareholder independence are focused on, complementing these with a study, and hence support, of the UK Corporate Governance Code.

A main contribution is to present variables indicating strong corporate governance structures, providing a guide to avoid financial problems of corrupt and weak company management with

\footnotetext{
1) The Financial Reporting Council (FRC), regulating accountants, auditors, actuaries and setting the UK's Corporate Governance and Stewardship Codes, is an independent regulator in the U.K. and Ireland.
} 
poor corporate governance; exploring U.K. market characteristics further and deepening our understanding of how U.K. companies can increase the effectiveness of their corporate governance and reduce bankruptcy likelihood. There is a lack of studies with empirical evidence of the U.K. market with a direct approach to the U.K. Corporate Governance Code.

We will show that ownership concentration, board size, independence of shareholders and level of director remuneration are highly significant but negatively related with U.K. company financial distress likelihood. In contrast, corporate loans appear closely linked to financial distress: companies with corporate loans appear more likely to incur financial distress.

\section{Literature Review}

\subsection{Corporate Governance, Financial Distress, and their relationship}

Company performance has a direct relationship with corporate governance and how companies are managed (Yu, 2011; Hodgson et al, 2011). Corporate governance is 'the system by which companies are directed and controlled' (Financial Reporting Council) in which managers and directors of companies (Handley-Schachler et al, 2007) mainly implement that system.

Financial distress is associated with at least a company's incapacity to pay obligations or debt when due (Geng et al, 2015); financial debt is the main cause of financial distress or default for Pham Vo Ninh et al (2018).

Models have been created to predict financial distress (Altman, 1968; Pindado et al, 2008; Daily, 1996; Khoja et al, 2019; Kahl, 2002). They are useful to anticipate and understand companies' financial signals before a collapse or a recession period; so companies, investors, creditors, regulators and stakeholders can better understand how to avoid a bankruptcy situation through application of important strategies and good management actions.

The relationship between financial distress and governance has been investigated in prior studies (Manzaneque, 2016; Darrat et al, 2016; Daily, 1996; Siddiqui, 2015; Opler et al, 1994), the consensus being that financial distress may occur when shareholders, directors or CEOs make decisions more in favour of themselves than the company. In short, corporate governance structures and characteristics can have a strong influence on company performance and can prompt financial distress or bankruptcy. 


\subsubsection{Agency problems}

The question of agency theory in a corporate governance context has been explored (Berle and Means, 1932; Eisenhardt, 1989; Shleifer and Vishny, 1997; Hong, 2019). It potentially happens when shareholders and directors choose strategies mainly or only benefitting themselves.

Companies have collapsed due to agency problems, or through corporate governance structure complications; with weaknesses of corporate governance and conflicts of interest leading to financial distress; in turn, inducing company collapses, destroying stakeholders and significantly (Davis, 1993; Dibra, 2016). Examples of weak corporate governance inducing large collapses are Enron, WorldCom, Sunbeam, Tyco, and Xerox. Aspects of corporate governance and board strategy failed in Enron (Gillan and Martin, 2007). A conflict of interest between board members led to manipulation of asset values, prices and financial positions.

Agency theory helps us understand how problems with corporate governance directly impacts financial distress likelihood. Companies can easily fall into agency problems, prejudicing their financial system, without a well-structured board; with even money laundering, bribery, tax evasion or other financial frauds occurring. Bad management and corporate governance deficiencies can have global implications for stakeholders.

\subsubsection{UK Corporate Governance Code}

The Financial Reporting Council (FRC) is the entity responsible for U.K. corporate governance regulations and the UK Corporate Governance Code represents the main guidance code; aiming to respond to challenges brought about by corporate governance weaknesses revealed in huge firm collapses around the world. (FRC, 2019).

The Code's basic principles concern Board members' responsibilities and independence, intending to stimulate boards to think how their roles should be exercised effectively in favour of their companies. Strong corporate governance is based on values of independence, responsibility, transparency, and effective monitoring; values intended to support long-term sustainability and success in companies and protect stakeholders, avoiding agency problems.

\subsection{Corporate Governance Variables as Financial Distress Measure(s)}

\subsubsection{Ownership Concentration}

How is ownership concentration, either dispersed (with minority shareholders) or concentrated (with large and controlling shareholders), linked with financial distress? Claessens et al (2002) 
and Alhares (2020) believe there is a negative relationship between ownership concentration and financial distress. Large shareholders are highly interested in the company’s welfare: ‘...incentive to have the firm run properly, because...(doing so) would raise his wealth; likewise, his incentive to reduce the value of the firm by extracting private benefits is weaker, because doing so would lower his wealth' (Claessens et al, 2002, p. 2754). Shleifer and Vishny (1986) agree large shareholders are strongly motivated to monitor the firm effectively. Consequently, it is believed large shareholders positively influence company management, improving performance, and mitigating agency problems or conflicts of interest.

\subsubsection{Independence of Company's Shareholders and Directors}

A company may have a high degree of independence if it shows a particular percentage of shareholder ownership. The bulk of the literature supports the need for an independent company with independent shareholders and directors facilitating proper management of the business. Following agency theory, board independence is crucial to ensure a company's requirements are respected, without selfish or exploitative behaviour occurring. Independent directors reinforce Boards, bringing further knowledge and additional outside influence (Kesner et al, 1986); an independent structure better supports the interests of shareholders.

Independence allows a diversity of information and can contribute to decreasing agency problems (Daily and Dalton, 1994a). The UK Corporate Governance Code indicates companies should remain independent with a board mostly consisting of independent, non-executive members (FRC, 2019).

\subsubsection{Board Size}

Board size is considered significant and essential in determining management quality and company performance. A large board size benefits company performance (Fox, 1998); suggesting that firms with small boards are more likely to incur financial distress due to their incapacity to collect necessary resources to guarantee their survival. Darrat et al (2016) associate large boards with an improvement in companies' operating performance, with that association being stronger in large and complex firms. Large boards can provide an overall knowledge increase for the company, allowing a variety of perspectives, possibly contributing to a reduction in financial distress likelihood (Pfeffer, 1973).

Boards of Directors are responsible for taking decisions influencing companies' financial health. Their power to delegate, hire and fire executives, accept loans, and define dividend and options 
policies financially affect companies. Agency theory explains how companies under financial distress can decline when boards display conflict or take unreasonable decisions.

\subsubsection{CEO Duality}

With CEO duality, company chairman and chief executive officer (CEO) roles are not separated: the same person occupies both positions. The literature is controversial:

Agency theory recommends separate chair and CEO roles because duality could lead to selfserving behaviour, occasioning a cost for the firm's owners (Daily and Dalton, 1994b).

Stewardship theory argues the CEO/Chair intends to do a good job and be recognized as a good steward of company value; the company benefits from a strong command, leadership is simplified, and shareholders returns improve with CEO duality (Donaldson and Davis, 1991).

The UK Corporate Governance Code believes the chair and chief executive officer roles should be exercised by different people, aiming to maintain board independence (FRC, 2019).

\subsubsection{Directors' Remuneration}

For Lee (2009), company performance increases with performance-related payment(s) to directors; contracts lacking financial incentives to the CEO characterised companies with poor performance. Perry and Zenner (2001) suggest a positive impact between overall pay and director performance, and these contracts appear to be increasing, apparently achieving better results for companies. Director remuneration should reflect shareholder wealth and firm performance (Monem and $\mathrm{Ng}$, 2013). Directors and managers have therefore an interest in maintaining shareholder wealth: an increase in managerial effort it is believed results from linking shareholder and director wealth with company performance.

Agency theory believes remuneration creates director incentive to perform well, positing that compensation contracts and high payment to directors may reduce agency costs (Conyon and He, 2011). The UK Corporate Governance Code believes a director should not be involved in decisions related to their own remuneration, but rewards should be aligned with the financial capacity and company performance (FRC, 2019).

It is believed directors need high remuneration and high recognition when managing companies; it is an immense responsibility and directors will perform well if they feel their efforts will be compensated in line with company results. The negative relationship between director remuneration and financial distress likelihood will be examined. 


\subsubsection{Corporate Loans}

Loans are important for corporate financing, allowing companies to increase their liquidity in a short time (McKeon, 1969). Firms' capital structures include debts and loans, increasing their investment or cash. Companies can reduce the costs of increasing equity through shareholder funds (DeAngelo et al, 2011). Loans and debt have clear advantages, but the cost should not be overlooked. Borrowing costs can be high. Low management effectiveness with external factors and a high cost of debt can bring firms into financial distress. This paper explores how loans are linked with financial distress.

Parlour and Winton (2013) consider a situation where possession of a loan results in company default. A high number of covenants give the bank the advantage when a company violates some of the clauses. Banks take opportunity of the advantage, increasing interest rates and decreasing the quality of the borrower's loan. Rajan et al (2015) empirically demonstrate that an interest rate increase on a company's loans is a default predictor. Hence, companies should undertake appropriate management control to avoid contract violations or situations putting them at risk of default. Demiroglu and James (2015) found a positive relationship between loans (with collateral obligations) and predisposition to bankruptcy.

\subsection{Other Control Variables: Financial Ratios and Company Age}

Corporate governance's position in financial distress will be explored, but a look at financial theory to predict financial distress is crucial (Pindado et al, 2008). This study's regression is supported by financial ratios based on the Pindado model: Financial Expenses and Retained Earnings. Financial Expenses $\left(\mathrm{FE}_{\mathrm{t}} / \mathrm{RTA}_{\mathrm{t}-1}\right)$ is the explanatory variable associated with the financial expenses a company needs to cover. Retained Earnings $\left(\mathrm{RE}_{\mathrm{t}-1} / \mathrm{RTA}_{\mathrm{t}-1}\right)$ is the explanatory variable associated with a firm's earnings or losses during its life.

Company Age is a control variable. Altman (1968) showed that young firms have a higher chance of being classified as financially distressed. Due to their limited years of life, they do not have the opportunity to accumulate profit over time.

\subsection{Hypothesis}

The previous section's variables will be tested to determine association with financial distress, and utilised in the next section through a binominal logistic regression to test the following hypotheses: 
H1: Ownership concentration and company independence are negatively related to financial distress.

$\mathrm{H} 2$ : A large board size is negatively related to financial distress

H3: Director remuneration is negatively related to financial distress

H4: Corporate loans are positively related to financial distress.

H5: CEO Duality is positively related to financial distress.

\section{Framework and Model Development}

This paper emphasises financial and corporate governance components, therefore the Pindado et al (2008) and Manzaneque et al (2016) models were followed to ascertain how corporate governance influences financial distress likelihood. Based on these models, a framework was constructed, including certain variables, resulting in:

$$
\begin{aligned}
& F D=\beta_{0}+\beta_{1} F E+\beta_{2} R E+\beta_{3} O W N E R S_{t}+\beta_{4} I N D_{t}+\beta_{5} B S+\beta_{6} C E O D+d_{t}+ \\
& n_{i}+u_{i t}
\end{aligned}
$$

Where: FD represents Financial Distress; FE is the ratio $\mathrm{FE}_{\mathrm{it}} / \mathrm{RTA}_{\mathrm{it}-1} ; \mathrm{RE}$ is the ratio $\mathrm{RE}_{\mathrm{it}-1} / \mathrm{RTA}_{\mathrm{it}-}$ 1; OWNERS is the percentage of Ownership Concentration (total of shares owned by large shareholders); IND represents the level of Shareholder Independence (based on the BvD Independence Indicator) ${ }^{2}$; BS is Board Size (number of Board members); CEOD represents CEO Duality $^{3}$. Table 2 presents a detailed description.

According to the models from Perry and Zenner (2001) and Lee (2009), executive remuneration is valuable to measure company performance. Expecting higher director remuneration to reduce financial distress likelihood, the variable 'DR', representing Directors' Remuneration, was introduced into the model.

Complementing the model, a regression was performed examining how corporate loans can be associated with the probability of financial distress occurring; hence the variable ' $\mathrm{CL}$ ', Corporate Loans, was introduced into the model.

Resulting in the final model:

\footnotetext{
${ }^{2} \mathrm{BvD}$ Independence Indicator: indicator created by Bureau van Dijk to characterise degree of a company's independence relating to its shareholders.

${ }^{3}$ CEO Duality: dummy variable taking value 1 when chairman and CEO positions are exercised by same person and 0 otherwise.
} 


$$
\begin{aligned}
& F D=\beta_{0}+\beta_{1} F E+\beta_{2} R E+\beta_{3} A G E+\beta_{4} O W N E R S+\beta_{5} I N D+\beta_{6} B S+\beta_{7} C E O D+ \\
& \beta_{8} D R+\beta_{9} C L+d_{t}+n_{i}+u_{i t}
\end{aligned}
$$

Table 2 describes the explanatory variables: $d_{t}, n_{i}$ and $u_{i t}$ represent time effect, individual effect, and random disturbance, respectively. Coefficients of the equation are given by Betas: $\beta_{0}$ representing the constant of the model, and the remaining Betas representing the explanatory variables' behaviour.

The final equation (2) incorporates two approaches: firstly, incorporating financial ratios to measure financial distress likelihood, providing an overview of how a company is performing financially; secondly, incorporating corporate governance variables proven to be associated with companies' financial performance. A binomial logistic is used in the final econometric model, since the dependent variable (financial distress) is binary; assuming the value 0 when the company is not considered in financial distress and 1 when the company is in financial distress.

\section{Data and Sample Selection}

A quantitative approach is used to analyse the impact of corporate governance structures on financial distress likelihood in British companies. The Fame database was used to collect all financial and corporate governance data.

A sample of 270 U.K. listed companies was used for nine years from 2010 to 2018. From 1,992 companies' data, financial services companies were excluded from the sample: they can present features potentially compromising the study's essence; high levels of leverage, for example, not usually present in non-financial companies (Fama and French, 1992).

All inactive companies were excluded, companies not including their latest available accounts data in 2018, alongside companies with missing data between 2010 to 2018. Table 1 displays the sample selection process. Companies were matched by total average assets and classified as financially distressed or non-distressed; distressed when they had at least one year of distress in the period under consideration. In this sense, therefore, the sample was performed based on a one-year firmobservation. Following Pindado et al (2008), the companies were deemed distressed when they

met one of the following: their EBITDA was lower than their financial expenses for two consecutive years; or a fall in their market value occurred between two consecutive periods.

\section{Insert Table 1}


The final sample had 270 firm-observations, including 135 financially distressed and 135 nondistressed firms. Companies were chosen by the criteria of highest total average assets.

Table 2 presents variable descriptions and definitions for analysis of this sample, analysing a sample of 30 companies in each year, totalling 270 firm-observations. The study uses a crosssectional logistic regression to analyse the different companies in the different years, with 50 per cent of the companies considered financial distressed and 50 per cent considered not distressed.

\section{Insert Table 2}

Table 3 shows the sample distribution per industry, using the Standard Industrial Classification (SIC Code) and excluding financial services companies. More predominant industries were mining and quarrying, manufacturing, and professional and scientific and technical activities, although the sample contains companies from all industries.

\section{Insert Table 3}

\section{Descriptive statistics and Correlation}

Table 4 shows that the variables' descriptive statistics are consistent with past research. Reviewing Board Size and Ownership Concentration, they are consistent with Elmagrhi et al (2017). It is expected that U.K. companies have on average approximately eight Board members and reveal a relatively low concentration of ownership. This is confirmed by the present study with average ownership concentration being 29 per cent. Considering the BvD Independence indicator, U.K. companies are evidently mainly independent - encouraging, considering the UK corporate governance recommendation of independent boards. Remuneration also needs to be fair, according to the FRC (2019), and U.K. directors on average have a remuneration of 2 million pounds.

Table 4.1 presents the categorical variables' descriptive statistics: most U.K. companies had a corporate loan in the analysis period - expected, since loans are a direct way of obtaining financing; most U.K. companies do not have CEO duality, consistent with Guest (2008).

Table 5 presents the descriptive statistics by group (distressed and non-distressed companies). Fig.1 shows the financial expenses for non-distressed and distressed firms during 2010 to 2018. As expected, financially distressed companies present higher financial expenses and lower retained 
earnings. Except for 2011, with the largest negative retained earnings, non-distressed firms' financial expenses are lower than distressed firms for the remaining years.

\section{Insert Table 4 and Table 4.1}

Figures 1 and 2 show the Financial Expenses and Retained Earnings for non-distressed and distressed firms for 2010 to 2018. The results indicate that companies in difficulties have lower or negative retained earnings resulting from a succession of losses for the sample period, 2010 to 2018 .

\section{Insert Figures 1 and 2}

In analysing corporate governance variables, there is a noticeable difference between distressed and non-distressed company characteristics. For example, with Ownership concentration and BvD independence, distressed companies show lower ownership and independence, consistent with Claessens et al (2002) and Kesner et al (1986). Darrat et al (2016) concluded that companies perform better with a larger board. This is confirmed, since non-distressed companies have a larger board size with approximately eight members. With director remuneration, there is a high discrepancy between the two groups: distressed companies offered directors a lower remuneration ( 0.9 million pounds on average) than non-distressed companies (3.172 million on average). Table 5 also presents the t-test and concludes there is a significance of the means for the financial expenses, retained earnings, age, independence indicator and director remuneration variables.

For the categorical variables, CEO duality and corporate loans, a chi-square test was performed to check the association with the financial distress variable (composed of two groups: distressed and non-distressed companies). Table 5.1 presents this test's results, and concludes there is a significant association with the corporate loans variable; the result of Pearson Chi-square was 15.28 per cent.

\section{Insert Table 5 and Table 5.1}

Table 6 shows the variables' correlations, through both Pearson and Spearman correlation coefficients and significance levels. As expected a priori, most corporate governance variables are 
significantly correlated with the financial distress variable. For example, there is an evident relationship between financial distress and $\mathrm{BvD}$ independence, board size, director remuneration and corporate loans. This conclusion is in line with previous research (Kesner et al, 1986; Darrat et al, 2016; Lee, 2009; and Demiroglu; James, 2015).

\section{Insert Table 6}

\section{Regression Results and Findings}

This study performs a binary logistic regression, taking a cross sectional dimension. In the model used, the dependent variable is a discrete binary (coded as 1 when companies are considered financially distressed and 0 otherwise), and the independent variables are continuous and discrete. Table 7 presents the results of the test performed after verifying the assumptions. The model appears statistically significant; the Chi-square from the Omnibus test is 214.24 per cent and the correspondent p-value is less than 0.001 .

\section{Insert Table 7}

Table 7 shows the logistic regression's summary results. The model aims to measure the impact of financial and corporate governance variables on financial distress likelihood. The model's results show that the variables of financial expenses, retained earnings, age, ownership concentration, independence indicator, board size, director remuneration, and corporate loans are significant when analysing UK companies' financial distress likelihood. However, CEO duality does not appear to have a high significance.

Considering the model's two financial ratios, the results are consistent with the literature (Altman, 1968; Pindado et al, 2008). As in the empirical studies of Pindado et al (2008) and Manzaneque et al (2016), financial expense is significant, having a positive relationship with financial distress likelihood. In the present model, it has a positive coefficient and is significant at the 1 per cent level $(\mathrm{p}=0.002)$.

Retained earnings has a high significance; its $\mathrm{p}$-value is significant at the 1 per cent level $(\mathrm{p}<0.001)$. Retained earnings is a ratio, part of profitability analysis over time. Companies with negative retained earnings are more likely to incur financial distress - consistent with Pindado et al (2008) who argued that companies' future capacity for self-financing may be affected by low or negative 
past profitability. Due to problems in self-financing, companies can quickly suffer financial distress or bankruptcy. In analysis of the retained earnings/total assets ratio, Altman (1968) adds that young firms have a higher chance of being classified as financially distressed. Due to their limited years of life, they do not have as much opportunity to accumulate profit over time, so there is a higher incidence of bankruptcy (Altman, 1968). The regression results confirm that company age impacts on financial distress likelihood; this variable has a negative coefficient, and is significant at the 10 per cent level $(\mathrm{p}=0.096)$.

The second part of the model shows reliable results, considering prior literature, demonstrating that Hypothesis 1 is supported: ownership concentration and company independence are negatively aligned with financial distress. Ownership concentration is significant at the 1 per cent level $(\mathrm{p}=0.004)$ and presents a negative coefficient, consistent with Claessens et al (2002) and Shleifer and Vishny (1986). It is widely believed large shareholders have a higher capacity for effective business monitoring. According to Shleifer and Vishny (1986), large shareholders have a higher interest in the business performing well and therefore avoid agency problems and conflicts of interest. Company independence, referring to shareholder independence, presents a similar result. The BvD independence indicator is significant at the 5 per cent level $(\mathrm{p}=0.013)$ and presents a negative coefficient. We can conclude that the independence level is aligned with better performance as agency problems may be mitigated. As supported by Kesner et al (1986), independent directors reinforce the board with knowledge and outside influence. The UK Corporate Governance Code demonstrates a similar view in supporting independent boards.

With the board size variable, Hypothesis 2 is confirmed: firms with large boards are less likely to incur financial distress. Board Size presents a negative coefficient with a significance at the 5 per cent level $(\mathrm{p}=0.047)$, indicating that firms with more members on the board might have a better financial performance. This is consistent with Darrat et al (2016) who associated large boards with an improvement in company operating performance. Fox (1998) and Pfeffer (1973) further support the result: with large boards, there is more capacity to collect necessary resources to help company performance. Additional board members can lead to more shared knowledge which contributes to better overall performance and reduces financial distress likelihood. In Manzaneque's (2016), empirical study, there is evidence of a negative relationship between board size and distress likelihood, concluding that companies with a higher number of board members have additional access to information and resources and are better able to control management. Moreover, a high number of board members supports a diversity of interests and viewpoints that, in the end, contributes to increased financial performance and reduces financial distress likelihood. 
With director remuneration, lower remuneration is evidently linked with the occurrence of financial distress, being significant at the 1 per cent level $(\mathrm{p}=0.001)$ with a negative coefficient. This supports previous theories believing higher remuneration generates higher motivation and increases company performance (Conyon and He, 2011). According to their research, company performance is strongly linked with compensation contracts of directors; and strong contracts contribute to relieving agency problems within the board. Hypothesis 3 is supported and sustained in part by the UK Corporate Governance Code stating the importance of having fair remuneration rewarding good performance, considering the company's financial capacity. The finding is consistent with Lee (2009) and Monem and $\mathrm{Ng}$ (2013) who argue for packages of remuneration for motivating executives and supporting positive company performance.

The results display a positive relationship between the existence of corporate loans and financial distress likelihood. Corporate loans are significant at the 1 per cent level $(\mathrm{p}=0.009)$ and present a positive coefficient, indicating that companies with loans are more prone to financial distress; consistent with studies such as Rajan et al (2015) and Demiroglu and James (2015). The present study's finding was expected since loans can incur high borrowing costs and increase default risk if companies have weaker capital structures. Boards and other corporate governance need to look at banks' conditions before signing loan contracts that may be unsuitable for the company. Hypothesis 4 is therefore supported: corporate loans are positively related to financial distress and this is consistent with previous research (DeAngelo et al, 2011; Parlour and Winton, 2013).

The CEOD variable is not significant within the model. It does not allow enough information to make further conclusions. The empirical result supports Rechner and Dalton's (1989) empirical study in which no relationship was found between CEO duality and company performance or financial distress likelihood.

In summary, the regression undertaken presents significant results supporting the impact of almost all the model's variables. It is concluded financial and economic and corporate governance variables are critical when studying or predicting financial distress or bankruptcy.

\section{Conclusion}

This paper offers an approach to studying U.K. companies' corporate governance characteristics and exploring how they can influence financial distress likelihood. It is evident that most corporate governance characteristics have an impact on financial distress likelihood. 
The model used addresses financial and corporate governance factors guaranteeing the results' quality. Variables examined to answer the main question set have been associated with financial distress by Altman (1968), Pindado et al (2008), Manzaneque et al (2016) and Lee (2009).

The study indicates that the main corporate governance variables are significant when predicting financial distress. It is concluded that ownership concentration, independence, board size and director remuneration present a negative relationship with financial distress. The research confirms that companies may guarantee themselves a better performance with a large ownership concentration and independence, since large shareholders may have more interest and motivation for effective monitoring, and independent directors in companies appear to help in the mitigation of agency problems. Regarding board size, it appears that a large board performs better than a smaller one; believed to be due to the diversity of knowledge and resources a large board can bring to the company. Director remuneration results appears in line with agency theory: higher remuneration increases director motivation and company performance.

We found a strong and positive relationship between corporate loans and financial distress. Companies financially distressed present a higher dependence on this type of loan but entail high costs some companies may not be able to pay.

The model focused on corporate governance measures. It also showed that financial ratios have a strong influence on financial distress occurrence, in line with other studies. The model demonstrated a high relationship between financial distress and financial expenses and retained earnings.

The research contributes to understanding how independence indicators, director remuneration and corporate loans contribute to financial distress likelihood. Companies should expect a decreasing likelihood of financial distress whilst there is: a high level of board independence; reduced corporate loans and consequently low risk of excessive debt; and directors are sufficiently well paid not to fall into incorrect and egoist decisions. These three variables play an important role in the U.K. market, but have apparently not been studied in the direct context of financial distress likelihood. This paper highlights and aggregates variables that have not otherwise been studied together. The empirical study has contributed to supporting the main ideas presented in the UK Corporate Governance Code (FRC, 2019). The study can be a useful tool to define corporate governance structure strategies.

Existing companies, new companies and researchers could benefit from the findings, adopting new corporate governance structures and strategies to improve company performance. There are three main recommendations. Firstly, companies and boards should consider forming independent 
boards where shareholders and directors are mainly independent. Secondly, companies should maintain a relatively high ownership concentration to guarantee shareholders have enough power to simplify and make decisions to run the business effectively. Thirdly, based on director remuneration and corporate loans: companies need to provide strong contracts packages to their directors, without compromising their financial wealth. Furthermore, companies should be aware of borrowing costs associated with corporate loans to ensure that they can afford the loan and pay the interest without any breach of contract, otherwise financial complications may occur.

\section{References}

Alhares, A. (2019), "Corporate governance and cost of capital in OECD countries", International Journal of Accounting \& Information Management, Vol. 28 No. 1, pp. 1-21.

Altman, E. (1968), "Financial Ratios, Discriminant Analysis and the Prediction of Corporate Bankruptcy", The Journal of Finance, Vol. 23 No. 4, pp. 589-609.

Berle, A. and Means, G. (1932), The Modern Corporation and Private Property, Commerce Clearing House, New York.

Chen, H. (2008), The Timescale Effects of Corporate Governance Measure on Predicting Financial Distress", Review of Pacific Basin Financial Markets and Policies, Vol. 11 No. 1, pp. 35-46.

Claessens, S., Djankov, S., Fan, J. and Lang, L. (2002), "Disentangling the Incentive and Entrenchment Effects of Large Shareholdings", The Journal of Finance, Vol. 57 No. 6, pp. 2741-2771.

Conyon, M. and He, L. (2011), "Executive compensation and corporate governance in China", Journal of Corporate Finance, Vol. 17 No. 4, pp. 1158-1175.

Daily, C. (1996), "Governance Patterns in Bankruptcy Reorganizations”, Strategic Management Journal, Vol. 17 No. 5, pp. 355-375.

Daily, C. and Dalton, D. (1994a), "Bankruptcy and Corporate Governance: The Impact of Board Composition and Structure", Academy of Management Journal, Vol. 37 No. 6, pp. 16031617.

Daily, C. and Dalton, D. (1994b), "Corporate governance and the bankrupt firm: an empirical assessment”, Strategic Management Journal, Vol. 15 No. 8, pp. 643-654.

Darrat, A., Gray, S., Park, J. and Wu, Y. (2016), "Corporate Governance and Bankruptcy Risk", Journal of Accounting, Auditing \& Finance, Vol. 31 No. 2, pp. 163-202.

Davis, M. (1993), "Conflict of Interest Revisited”, Business and Professional Ethics Journal, Vol. 12 No. 4, pp. 21-41.

DeAngelo, H., DeAngelo, L. and Whited, T. (2011), "Capital structure dynamics and transitory debt”, Journal of Financial Economics, pp. 235-261. 
Demiroglu, C. and James, C. (2015), "Bank loans and troubled debt restructurings", Journal of Financial Economics, Vol. 118 No. 1, pp. 192-210.

Dibra, R. (2016), "Corporate Governance Failure: the case of Enron and Parmalat", European Scientific Journal, Vol. 12 No. 16, pp. 283-290.

Donaldson, L. and Davis, J. (1991), "Stewardship Theory or Agency Theory: CEO governance and shareholder returns", Australian Journal of Management, Vol. 16 No. 1, pp. 49-64.

Eisenhardt, K. (1989), “Agency Theory: an assessment and review”, The Academy of Management Review, Vol. 14 No. 1, pp. 57-74.

Elmagrhi, M., Ntim, C., Crossley, R., Malagila, J., Fosu, S”, and Vu, T”, (2017), “Corporate governance and dividend pay-out policy in UK listed SMEs", International Journal of Accounting \& Information Management, Vol. 25 No. 4, pp. 459-483.

Fama, E. and French, K. (1992), "The Cross-Section of Expected Stock Returns", Journal of Finance, Vol. 47 No. 2, pp. 427-465.

Fox, M. (1998), Boards of Directors: the influence of board size, leadership and composition on corporate financial performance, Lincoln University Commerce Division, Lincoln.

Geng, R., Bose, I. and Chen, X. (2015), "Prediction of financial distress: an empirical study of listed Chinese companies using data mining", European Journal of Operational Research, Vol. 24 No. 1, pp. 236-247.

Gillan, S. and Martin, J. (2007), "Corporate governance post-Enron: effective reforms, or closing the stable door?", Journal of Corporate Finance, Vol. 13 No. 5, pp. 929-958.

Guest, P. (2008), "The determinants of board size and composition: evidence from the UK", Journal of Corporate Finance, Vol. 14 No. 1, pp. 51-72.

Hodgson, A., Lhaopadchan, S. and Buakes, S. (2011), "How informative is the Thai corporate governance index? A financial approach", International Journal of Accounting and Information Management, Vol. 19 No. 1, pp. 53-79

Hong, J. (2019), "Liquidity shocks, security design and organizational change", Revue économique, Vol. 70 No. 2, pp. 167-180.

Kahl, M. (2002), "Economic distress, financial distress, and dynamic liquidation", The Journal of Finance, Vol. 57 No. 1, pp. 135-168.

Kesner, I., Victor, B. and Lamont, B. (1986), "Board Composition and the Commission of Illegal Acts: an investigation of Fortune 500 companies", Academy of Management Journal, Vol. 29 No. 4, pp. 789-799.

Khoja, L., Chipulu, M. and Jayasekera, R. (2019), “Analysis of financial distress cross countries: using macroeconomic, industrial indicators and accounting data", International Review of Financial Analysis, Vol. 66 (101379), pp. 1-12.

Lee, J. (2009), "Executive performance-based remuneration, performance change and board structures", The International Journal of Accounting, Vol. 44 No. 2, pp. 138-162. 
Manzaneque, M., Priego, A. and Merino, E. (2016), "Corporate governance effect on financial distress likelihood: evidence from Spain”, Revista de Contabilidad, Vol. 19 No. 1, pp. 111-121.

McKeon, J. (1969), "Structure of Corporate External Financing”, Financial Analysts Journal, Vol. 25 No. 5, pp. 25-28.

Monem, R. and Ng, C. (2013), “Australia's 'two-strikes' rule and the pay-performance link: are shareholders judicious?", Journal of Contemporary Accounting \& Economics, Vol. 9 No. 2, pp. 237-254.

Ohlson, J. (1980), "Financial Ratios and the Probabilistic Prediction of Bankruptcy", Journal of Accounting Research, Vol. 18 No. 1, pp. 109-131.

Opler, T. C., \& Titman, S. (1994), "Financial distress and corporate performance", The Journal of Finance, Vol. 49 No. 3, pp. 1015-1040.

Parlour, C. and Winton, A. (2013), "Laying off credit risk: loan sales versus credit default swaps”, Journal of Financial Economics, Vol. 107 No. 1, pp. 25-45.

Perry, T. and Zenner, M. (2001), "Pay for performance? Government regulation and the structure of compensation contracts", Journal of Financial Economics, Vol. 62 No. 3, pp. 453-488.

Pfeffer, J. (1973), "Size, Composition, and Function of Hospital Boards of Directors: a study of organization-environment linkage", Administrative Science Quarterly, Vol. 18 No. 3, pp. 349-364.

Pham Vo Ninh, B., Do Thanh, T. and Vo Hong, D. (2018), "Financial distress and bankruptcy prediction: an appropriate model for listed firms in Vietnam", Economic Systems, Vol. 42 No. 4, pp. 616-624.

Pindado, J., Rodrigues, L. and de la Torre, C. (2008), "Estimating financial distress likelihood", Journal of Business Research, Vol. 61 No. 9, pp. 995-1003.

Rajan, U., Seru, A. and Vig, V. (2015), “The failure of models that predict failure: distance, incentives, and defaults", Journal of Financial Economics, Vol. 115 No. 2, pp. 237-260.

Rechner, P. and Dalton, D. R. (1989), "The Impact of CEO as Board Chairperson on Corporate Performance: evidence vs. rhetoric", Academy of Management Perspectives, Vol. 3 No. 2, pp. 141-143.

Shleifer, A. and Vishny, R. (1986), "Large Shareholders and Corporate Control", Journal of Political Economy, Vol. 94 No. 3, pp. 461-488.

Shleifer, A. and Vishny, R. (1997) "A Survey of Corporate Governance", Journal of Finance, Vol. 52, No. 2, pp.737-783.

Siddiqui, S.S. (2015), "The association between corporate governance and firm performance - a meta-analysis", International Journal of Accounting and Information Management, Vol. 23 No. 3, pp. 218-237.

Yu, M. (2011), "Analyst recommendations and corporate governance in emerging markets", International Journal of Accounting and Information Management, Vol. 19 No. 1, pp. 3452. 
Table 1. Sample Selection

Number of

Companies

U.K. Listed Companies

1992

Less:

Financial Services and Insurance Companies

$-688$

Inactive companies and without the latest accounts data available before 2018

$-413$

Companies without total assets available in the period

$-261$

Companies with other missing data

Companies not matched

Total Sample

270

Note: Our sample consists of 1,992 listed U.K. companies. SIC (Standard Industrial Classification) criteria were used to exclude Financial services and Insurances Companies (codes from 64 to 66). The final sample comprises 270 companies. The sample includes companies matched by highest total average assets. This study examines 270 companies based on one-year firm-observations. The sample includes 30 different companies per year (15 distressed and 15 non-distressed). 
Table 2. Variables Description

Variables $\quad \underline{\text { Definitions }} \quad \underline{\text { ABRV }}$

\section{Dependent Variable:}

Financial Distress

Dummy Variable: It takes the value 1 if the company is considered financially distressed and

FD the value 0 if the company is not considered financially distressed

\section{Independent Variables:}

\section{Financial and Control \\ Variables}

Financial Expenses

Retained Earnings

Company Age

\section{Corporate Governance Variables}

Ownership concentration

Independent Indicator

Board Size

CEO Duality

Director Remuneration

Corporate Loans
Financial expenses (Interest paid) divided by Total assets at the beginning of the period $\left(\mathrm{FE}_{\mathrm{t}} / \mathrm{RTA}_{\mathrm{t}-1}\right)$

Retained Profit or Losses divided by Total assets at the beginning of the period $\left(\mathrm{RE}_{\mathrm{t}} / \mathrm{RTA}_{\mathrm{t}-1}\right)$

Number of years since the company's incorporation

Percentage of shares owned by large shareholders (shareholders who own more than 3 per cent are considered large shareholders)

'BvD independence indicator': degree of independence of a company in respect to its shareholders. ${ }^{4}$

Number of members on the board of directors

Dummy Variable: taking the value 1 when the positions of Chairman and CEO are exercised by the same person, and the value 0 if the positions are exercised by different people.

Annual Remuneration of Directors (in millions)

Dummy Variable: it takes the value 1 when the company had a corporate loan in the year of analysis and 0 otherwise.

Note: The sign after each variable's name represents its positive (+) or negative (-) relationship between the likelihood of financial distress, based on the assumptions and examination of the present research.

\footnotetext{
${ }^{4}$ Measured on a scale between 1 to 8 , with 1 representing companies with direct shareholder ownership above $50 \%$ (high degree of ownership concentration) and 8 representing companies with more than 5 shareholders where the sum of ownership is above $75 \%$ (low degree of ownership concentration).
} 
Table 3. Sample distribution by industry

\begin{tabular}{|c|c|c|c|c|c|c|c|c|c|c|c|}
\hline \multirow{2}{*}{$\underline{\text { SIC Code }}$} & \multirow{2}{*}{$\frac{2010}{N}$} & \multirow{2}{*}{$\frac{2011}{N}$} & \multirow{2}{*}{$\frac{2012}{N}$} & \multirow{2}{*}{$\frac{2013}{N}$} & \multirow{2}{*}{$\frac{2014}{N}$} & \multirow{2}{*}{$\frac{2015}{N}$} & \multirow{2}{*}{$\frac{2016}{N}$} & \multirow{2}{*}{$\frac{2017}{N}$} & \multirow{2}{*}{$\frac{2018}{N}$} & \multicolumn{2}{|c|}{$\underline{\text { Total Sample }}$} \\
\hline & & & & & & & & & & $N$ & $\%$ \\
\hline 1 & 5 & 9 & 5 & 8 & 7 & 6 & 8 & 4 & 6 & 58 & $21 \%$ \\
\hline 2 & 7 & 1 & 4 & 6 & 5 & 8 & 4 & 7 & 7 & 49 & $18 \%$ \\
\hline 3 & 2 & 1 & 3 & 3 & 3 & 5 & 3 & 2 & 1 & 23 & $9 \%$ \\
\hline 4 & 4 & 2 & 5 & 1 & 3 & 2 & 5 & 2 & 1 & 25 & $9 \%$ \\
\hline 5 & 4 & 3 & 1 & 1 & 5 & 5 & 1 & 2 & 7 & 29 & $11 \%$ \\
\hline 6 & 2 & 1 & 2 & 2 & 1 & 0 & 0 & 1 & 1 & 10 & $4 \%$ \\
\hline 7 & 4 & 6 & 8 & 1 & 0 & 1 & 4 & 6 & 6 & 36 & $13 \%$ \\
\hline 8 & 1 & 3 & 0 & 5 & 3 & 0 & 2 & 3 & 1 & 18 & $7 \%$ \\
\hline 9 & 1 & 4 & 2 & 3 & 3 & 3 & 3 & 3 & 0 & 22 & $8 \%$ \\
\hline Total & 30 & 30 & 30 & 30 & 30 & 30 & 30 & 30 & 30 & 270 & $100 \%$ \\
\hline
\end{tabular}

Note: Table 3 presents the frequency of the sample in each industry during the period of study (2010 to 2018). The industries presented were based on the Standard Industrial Classification (SIC): Mining and Quarrying (1), Manufacturing (2), Construction (3), Wholesale and Retail Trade, Vehicles and Motorcycles (4), Information and Communication (5), Real Estate Activities (6), Professional and Scientific and Technical Activities (7), Administrative and Support Service Activities (8), and Other Services Activities (9). 
Table 4. Sample descriptive statistics

\begin{tabular}{|c|c|c|c|c|c|}
\hline & $\underline{\text { Mean }}$ & $\frac{\text { Standard }}{\text { Deviation }}$ & 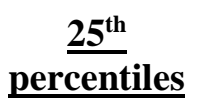 & $\underline{\text { Median }}$ & $\frac{75^{\text {th }}}{\text { percentiles }}$ \\
\hline \multicolumn{6}{|c|}{ Financial and Control Variables: } \\
\hline FE & 0.129 & 1.875 & 0.001 & 0.007 & 0.018 \\
\hline RE & -0.097 & 0.571 & -0.147 & -0.013 & 0.048 \\
\hline AGE & 30.900 & 27.335 & 14.000 & 19.000 & 34.000 \\
\hline \multicolumn{6}{|c|}{ Corporate Governance Variables: } \\
\hline OWNERS & 28.634 & 26.168 & 7.000 & 21.550 & 43.710 \\
\hline IND & 6.833 & 1.968 & 5.000 & 8.000 & 8.000 \\
\hline BS & 7.163 & 2.426 & 6.000 & 7.000 & 9.000 \\
\hline DR & 2.036 & 3.365 & 0.457 & 0.857 & 2.127 \\
\hline
\end{tabular}

Note: Table 4 presents the descriptive statistics of the sample of 270 firm-observations. It summarises the mean, median, standard deviation, $25^{\text {th }}$ percentile and $75^{\text {th }}$ percentile for numeric variables. The variables are presented in Table 2.

Table 4.1. Sample descriptive statistics for categorical variables

\begin{tabular}{ccc}
\hline Categorical Variables & $\underline{\text { Coded }}$ & $\frac{\text { Count }}{197}$ \\
CEOD & Coded 0 & 73 \\
& Coded 1 & 77 \\
CL & Coded 0 & 193 \\
\hline
\end{tabular}

Note: Table 4.1 describes the dummy variables: CEO Duality and Corporate Loans. They are coded 1 in each case where the position of chairman and CEO are exercised by the same person or where companies do have corporate loans. They are coded as 0 otherwise. 
Table 5: Comparison of means between distressed and non-distressed companies

\begin{tabular}{|c|c|c|c|c|c|c|c|c|c|c|}
\hline & \multicolumn{5}{|c|}{$\underline{\text { Non-Distressed Companies }}$} & \multicolumn{5}{|c|}{ Distressed Companies } \\
\hline & $\underline{\text { Mean }}$ & $\underline{\mathrm{SD}}$ & $\underline{\frac{25^{\text {th }}}{\text { percentiles }}}$ & $\underline{\text { Median }}$ & $\underline{\text { percentiles }}$ & $\underline{\text { Mean }}$ & $\underline{\mathrm{SD}}$ & $\stackrel{25^{\text {th }}}{\text { percentiles }}$ & $\underline{\text { Median }}$ & $\stackrel{75^{\text {th }}}{\text { percentiles }}$ \\
\hline \multicolumn{11}{|c|}{ Financial and Control Variables: } \\
\hline $\mathrm{FE}$ & 0.011 & 0.011 & 0.004 & 0.008 & 0.013 & 0.247 & 2.651 & 0.000 & 0.005 & 0.024 \\
\hline RE & 0.094 & 0.485 & 0.019 & 0.039 & 0.074 & -0.288 & 0.588 & -0.298 & -0.135 & -0.050 \\
\hline AGE & 38.015 & 31.473 & 15.000 & 23.000 & 54.000 & 23.785 & 20.186 & 14.000 & 16.000 & 25.000 \\
\hline \multicolumn{11}{|c|}{ Corporate Governance Variables: } \\
\hline OWNERS & 29.026 & 26.155 & 7.130 & 24.400 & 43.600 & 28.241 & 26.272 & 6.440 & 20.800 & 47.480 \\
\hline IND & 7.156 & 1.791 & 8.000 & 8.000 & 8.000 & 6.511 & 2.087 & 5.000 & 8.000 & 8.000 \\
\hline BS & 8.156 & 2.327 & 7.000 & 8.000 & 9.000 & 6.170 & 2.100 & 5.000 & 6.000 & 7.000 \\
\hline $\mathrm{DR}$ & 3.172 & 4.077 & 0.742 & 1.796 & 4.200 & 0.900 & 1.873 & 0.309 & 0.583 & 1.038 \\
\hline \multicolumn{11}{|c|}{$\begin{array}{l}\text { Note: Table } 5 \text { presents a comparison of the means for economic and corporate governance variables between non-distressed and distressed companies. The T } \\
\text { difference of means for the mean, median, standard deviation, } 25^{\text {th }} \text { percentile, } 75^{\text {th }} \text { percentile and the t-test for each variable. The sample consists of } 270 \text { firm- } \\
\text { and the variables are presented in Table } 2 . * \text { Significant at the } 10 \text { per cent level; } * * \text { Significant at the } 5 \text { per cent level; } * * * \text { Significant at the } 1 \text { per cent level }\end{array}$} \\
\hline \multicolumn{11}{|c|}{ Table 5.1. Statistics for Categorical variables and Pearson's chi-square test } \\
\hline & & \multicolumn{4}{|c|}{ Non-Distressed Companies } & \multicolumn{3}{|c|}{ Distressed Companies } & \multirow{2}{*}{\multicolumn{2}{|c|}{ Chi-square }} \\
\hline Categorical Variables & $\underline{\text { Coded }}$ & Count & \multicolumn{2}{|c|}{$\underline{\%}$} & & Count & \multicolumn{2}{|c|}{$\underline{\%}$} & & \\
\hline \multirow{2}{*}{ CEOD } & Coded 0 & 103 & \multicolumn{2}{|c|}{$76 \%$} & & 94 & \multicolumn{2}{|r|}{$70 \%$} & \multirow{2}{*}{\multicolumn{2}{|c|}{1.521}} \\
\hline & Coded 1 & 32 & \multicolumn{2}{|c|}{$24 \%$} & & 41 & \multicolumn{2}{|r|}{$30 \%$} & & \\
\hline \multirow{2}{*}{$\mathrm{CL}$} & Coded 0 & 24 & & $18 \%$ & & 53 & & $39 \%$ & \multirow{2}{*}{\multicolumn{2}{|c|}{$15.280^{* * * *}$}} \\
\hline & Coded 1 & 111 & & $82 \%$ & & 82 & & $61 \%$ & & \\
\hline
\end{tabular}

Note: Table 5.1 presents categorical variables statistics for non-distressed and distressed companies and the Pearson's chi-square test to test the association with the Financial Distress variable. It is coded 1 in each case where the position of chairman and CEO are exercised by the same person or where companies do not have corporate loans. It is coded as 0 otherwise. ${ }^{* * *}$ Significant at the 1 per cent level. 
Table 6. Pearson and Spearman correlation coefficients

\begin{tabular}{|c|c|c|c|c|c|c|c|c|c|c|}
\hline & $\underline{\text { FD }}$ & $\underline{\mathbf{F E}}$ & $\underline{\mathbf{R E}}$ & $\underline{\mathbf{A G E}}$ & OWNERS & $\underline{\text { IND }}$ & $\underline{\mathbf{B S}}$ & CEOD & $\underline{\text { DR }}$ & $\underline{\mathbf{C L}}$ \\
\hline FD & & -0.068 & $-.728 * *$ & $-.269 * *$ & -0.020 & $-.193 * *$ & $-.423 * *$ & 0.075 & $-.513 * *$ & $-.238 * *$ \\
\hline p-value & & 0.269 & 0.000 & 0.000 & 0.738 & 0.001 & 0.000 & 0.219 & 0.000 & 0.000 \\
\hline $\mathrm{FE}$ & 0.063 & & 0.002 & $.133 *$ & -0.042 & -0.059 & $.237 * *$ & -0.034 & $.206 * *$ & $0.590 * *$ \\
\hline$p$-value & 0.301 & & 0.973 & 0.029 & 0.491 & 0.335 & 0.000 & 0.583 & 0.001 & 0.000 \\
\hline $\mathrm{RE}$ & $-.335^{* *}$ & $-.399^{* *}$ & & $.248 * *$ & 0.007 & 0.060 & $.291^{* *}$ & -0.112 & $.419 * *$ & $0.133^{*}$ \\
\hline p-value & 0.000 & 0.000 & & 0.000 & 0.909 & 0.327 & 0.000 & 0.065 & 0.000 & 0.029 \\
\hline AGE & $-.261^{* *}$ & -0.036 & 0.094 & & -0.098 & 0.028 & $0.138 *$ & 0.005 & $.243 * *$ & $0.219 * *$ \\
\hline$p$-value & 0.000 & 0.560 & 0.123 & & 0.108 & 0.651 & 0.024 & 0.934 & 0.000 & 0.000 \\
\hline OWNERS & -0.015 & -0.031 & -0.015 & $-.130^{*}$ & & $-.209 * *$ & -0.106 & -0.105 & $-.143^{*}$ & -0.059 \\
\hline$p$-value & 0.806 & 0.614 & 0.805 & 0.033 & & 0.001 & 0.081 & 0.086 & 0.018 & 0.334 \\
\hline IND & $-.164^{* *}$ & $-.182^{* *}$ & 0.012 & 0.031 & $-0.276^{* *}$ & & $0.143 *$ & $-0.125 *$ & $.177 * *$ & 0.016 \\
\hline$p$-value & 0.000 & 0.003 & 0.849 & 0.612 & 0.000 & & 0.018 & 0.041 & 0.003 & 0.799 \\
\hline $\mathrm{BS}$ & $-.410^{* *}$ & 0.047 & 0.047 & $.195^{* *}$ & $-0.124^{*}$ & 0.103 & & -0.027 & $.633 * *$ & $0.246^{* *}$ \\
\hline p-value & 0.000 & 0.444 & 0.440 & 0.001 & 0.042 & 0.091 & & 0.657 & 0.000 & 0.000 \\
\hline CEOD & 0.075 & -0.038 & 0.001 & -0.025 & -0.074 & -0.101 & -0.013 & & -0.097 & -0.003 \\
\hline p-value & 0.219 & 0.538 & 0.992 & 0.683 & 0.227 & 0.097 & 0.826 & & 0.113 & 0.956 \\
\hline DR & $-.338^{* *}$ & -0.035 & 0.095 & 0.097 & $-0.214^{* *}$ & $0.125^{*}$ & $0.510^{* *}$ & 0.032 & & $0.240 * *$ \\
\hline p-value & 0.000 & 0.568 & 0.121 & 0.111 & 0.000 & 0.040 & 0.000 & 0.600 & & 0.000 \\
\hline $\mathrm{CL}$ & $-.238^{* *}$ & 0.043 & 0.052 & $.204^{* *}$ & -0.063 & 0.013 & $0.239^{* *}$ & -0.003 & $0.143^{*}$ & \\
\hline p-value & 0.000 & 0.485 & 0.398 & 0.001 & 0.305 & 0.829 & 0.000 & 0.956 & 0.019 & \\
\hline
\end{tabular}

Note: Table 6 provides the Pearson correlation (below diagonal) and Spearman correlation (above diagonal) between all variables. The sample consists of 270 firm-observations and the variables are presented in Table 2. ** Correlation is significant at the 1 per cent level; * Correlation is significant at the 5 per cent level. 
Table 7. Logistic Regression

\begin{tabular}{|c|c|c|}
\hline & $\boldsymbol{\beta}(\mathbf{S . E})$ & Significance \\
\hline Financial Expenses (FE) & $43.860(14.108) * * *$ & 0.002 \\
\hline Retained Earnings (RE) & $-14.060(2.325) * * *$ & 0.000 \\
\hline Company Age (AGE) & $-.014(0.008) *$ & 0.096 \\
\hline Ownership Concentration (OWNERS) & $-.024(.009) * * *$ & 0.004 \\
\hline BvD Independence indicator (IND) & $-.286(.115) * *$ & 0.013 \\
\hline Board Size (BS) & $-.225(.113) * *$ & 0.047 \\
\hline CEO Duality (CEOD) & $.240(.478)$ & 0.615 \\
\hline Director's Remuneration (DR) & $-.548(.163) * * *$ & 0.001 \\
\hline Corporate Loans (CL) & $1.311(.498) * * *$ & 0.009 \\
\hline Constant & $3.803(1.223)$ & 0.002 \\
\hline Number of observations & 270 & \\
\hline-2 Log likelihood & 160.06 & \\
\hline Model Chi-square (Omnibus test) & $214.239 * * *$ & \\
\hline Cox \& Snell R Square & 0.548 & \\
\hline Nagelkerke R Square & 0.73 & \\
\hline
\end{tabular}

Note: Table 7 shows the results of logistic regression. The regression used was a binomial logistic since the dependent variable (Financial Distress) is binary. The sample consists of 270 firm-observations and the variables are presented in Table 2. *Significant at the 10 per cent level. **Significant at the 5 per cent level. ***Significant at the 1 per cent level. 


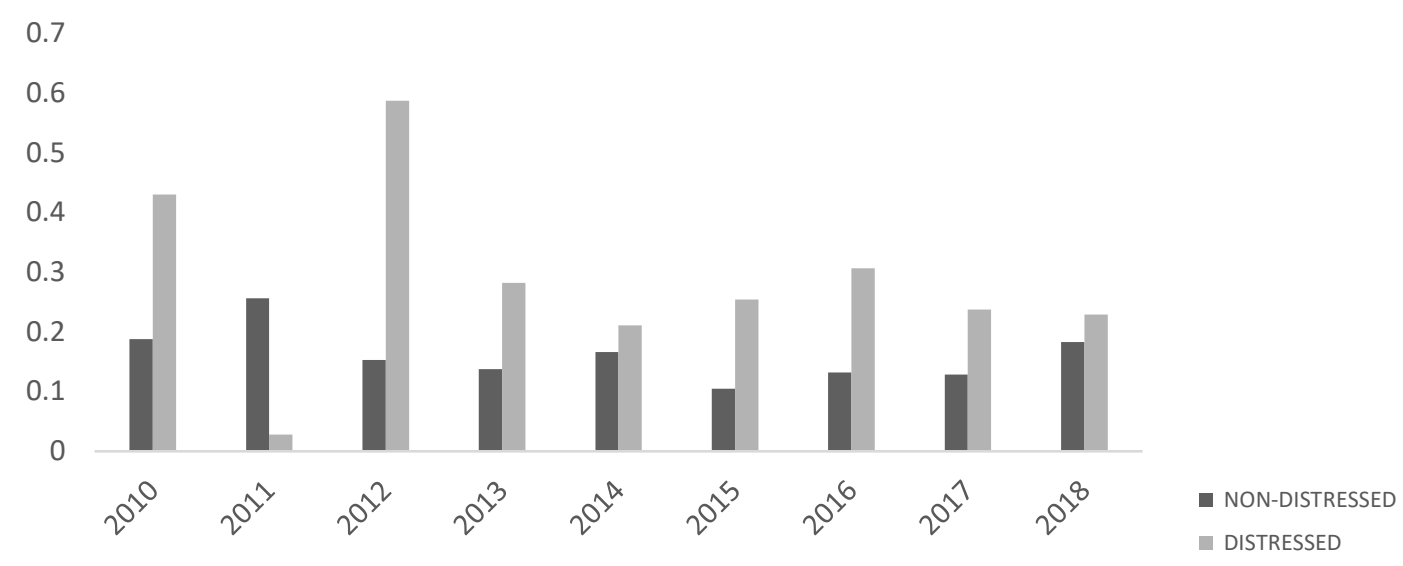

Fig. 1. Financial Expenses.

Above graph shows the financial Expenses of Non-Distressed and Distressed firms for the 2010-2018 period. Financial expenses are calculated as follows; Interest Paid divided by Total assets at the beginning of the period $\left(\mathrm{FE}_{\mathrm{t}} / \mathrm{RTA}_{\mathrm{t}-1}\right)$, as referenced in Table 2 .

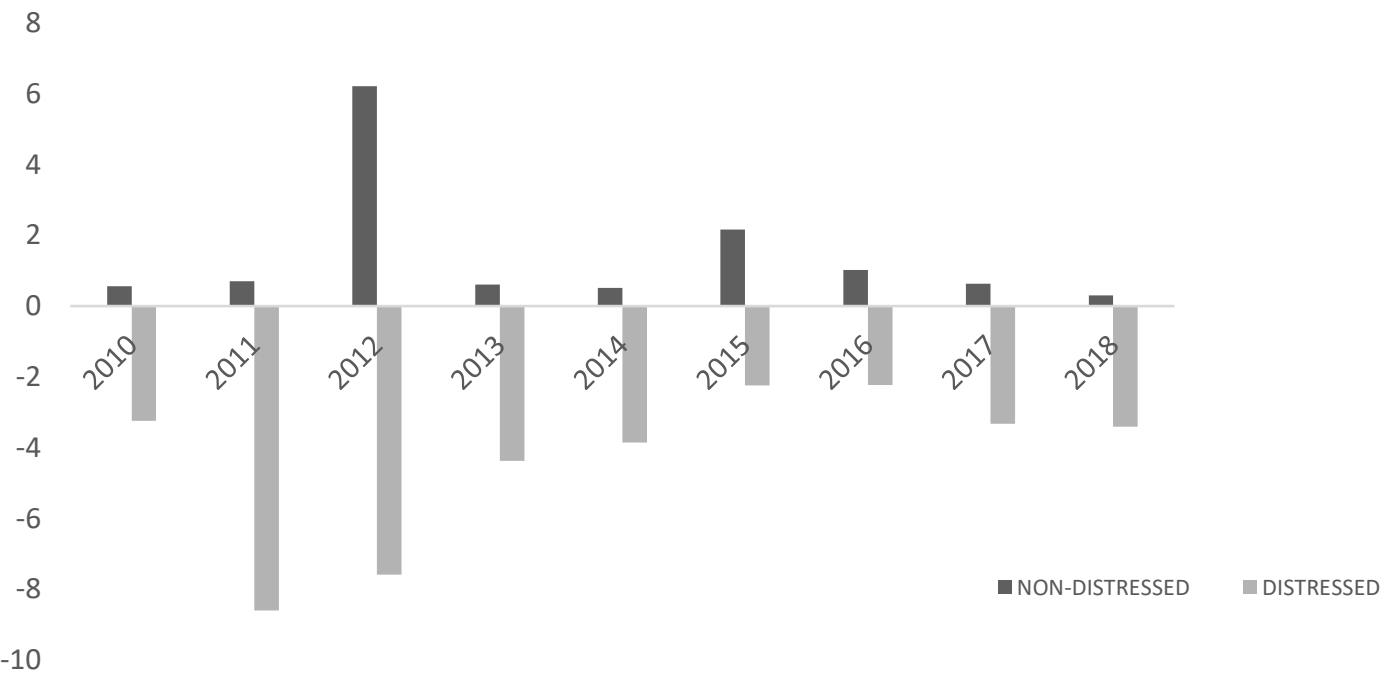

Fig. 2. Financial Expenses.

Fig.2 illustrates the retained earnings of Non-Distressed and Distressed firms for the 2010-2018 period. Retained earnings are calculated as follows; Retained Profit or Losses divided by Total assets at the beginning of the period $\left(\mathrm{RE}_{\mathrm{t}} / \mathrm{RTA}_{\mathrm{t}-1}\right)$ as referenced in Table 2. 